\title{
An Analytical Framework for Analysing Secondary EFL Writing Curriculum: Approaches for Writing and Preparation for Higher Education
}

\author{
Fatima Al-Hammadi ${ }^{1,2}$ \& Harison Mohd Sidek ${ }^{1}$ \\ ${ }^{1}$ Faculty of Major Language Studies, Universiti Sains Islam Malaysia, Malaysia. \\ ${ }^{2}$ English Language Department, University of Science and Technology, Sana'a, Yemen \\ Correspondence: Harison Mohd Sidek, Faculty of Major Language Studies, Universiti Sains Islam Malaysia \\ (USIM), Bandar Baru Nilai, 71800 Nilai, Negeri Sembilan, Malaysia. E-mail: harison@usim.edu.my
}

\author{
Received: September 19, 2014 Accepted: October 30, 2014 Online Published: December 30, 2014 \\ doi:10.5539/ies.v8n1p59 \\ URL: http://dx.doi.org/10.5539/ies.v8n1p59
}

\begin{abstract}
Academic writing is perhaps the most important skill required in higher education learning for the purposes of academic communication, academic performance, as well as academic achievement and success. However, many studies carried out in an EFL context showed that the majority of students face difficulties and challenges in acquiring effective academic writing skills. Furthermore, it has been reported that most writing problems students face at a university level seem to be associated with certain deficits in the preparation process at the secondary level with regards to both curriculum and instruction. Consequently, this research presents an analytical framework for analysing EFL secondary writing curriculum in order to help educational institutions, curriculum designers and educators to develop the EFL writing curriculum for secondary schools, in addition to promoting effective teaching and learning strategies that will equip students with the writing skills they need at the higher education level.
\end{abstract}

Keywords: SLA theories, EFL writing theories, EFL writing curriculum, academic writing, secondary, higher education, Richards and Rodgers model

\section{Introduction}

English is now considered to be an international language (Jung \& Norton, 2002; McKay, 2002) and the universal language of communication (Crystal, 2003). In the higher education context, language proficiency is an important factor for those aspiring toward academic success and achievement (Stoynoff, 1997; Songy, 2007). In particular; effective writing skills are essential for success in higher educational learning (Ahmed, 2010; Hasbollah, 2010), work (Kellogg \& Raulerson, 2007; Prior, 2012) and society (Prior, 2012).

In order for students studying at the university level to succeed and find their academic path, it is essential for them to acquire a good level of academic writing and communication. Writing skills are important for academic performance as well as performance at work (Stoynoff, 1997; Kellogg \& Raulerson, 2007). In education, writing is a means by which students can communicate professionally with instructors and peers, facilitating the conduct of a set of teaching and learning activities (Reigstad, 2008). The importance of writing lies in its extensive use within education and the workplace. In the workplace, college graduates should have effective communication and writing skills so that they are able to manage daily operations, make decisions as well as document and report large amounts of complex information (Jones, 1995).

Of all English language skills, writing remains the most important (Reigstad, 2008), yet difficult skill (Gabrielatos, 2000) for those in the process of picking up a language. This is due to the fact that learners are required to possess a certain degree of pre-existing awareness of the language they are learning such as vocabulary; accurate word and phrase usage; and rhetorical technique with which to persuasively convey information to the reader (Tangpermpoon, 2008). Myles (2002) argued that writing is a complex language skill learned through a process of instruction. Writing requires formal learning through sets of practices in formal instructional settings. First, it is necessary to master the written code as well as certain structures common to the language format, after which it is necessary "...to comprehend how to arrange and order concepts in a certain way so that they may be conceived by a reader who may not be known or nearby" (Byrne, 1988, p. 5). The 
technique of writing is considered to be a challenge for EFL students as part of the larger process of learning a language, as asserted by Richards and Nunan (1990), and, regarding the opinions of Richards and Renandya (2002) whose challenges exist in; 1) the creation and ordering of concepts through the correct word use, and (2) putting such ideas into intelligible text.

Writing is an important skill that all language learners need to develop as it is not only a means to reinforce grammatical structures, idioms and vocabulary, but it also allows for communication through a different medium requiring the appropriate use of linguistic skills (Eming, 1978). With regards to competency, the ability to create a cogent, flowing segment of extended text is one of the most demanding skills one may develop in learning a language; and it remains something that even most native speakers never truly master (Nunan, 1999). For L2 learners in particular, learning to write successfully in English can be an overwhelming task due to the fact that they are required to realize the changes from their native tongue, as well as the L2 as a result of speaking two languages.

Nunan (2003) argued that creating a cogent piece of writing is an exertion for all English learners, including those who speak English as a mother-tongue. White and Arndt (1991) argued that an aptitude for a particular language "does not alleviate the difficult of langue on its own". The authors explained that; "individuals writing in their first language, despite the fact that they may possess a larger cache of linguistic techniques, often are faced with similar challenges as those writing in their second or third language." If writing coherently and clearly is a skill that native speakers find difficult, L2 learners-who have less experience in English and its many idiosyncrasies and conventions-will certainly find it a difficult task, and one that takes time and considerable effort.

For those attending further education English as a Second Language (ESL) as well as English as a Foreign Language (EFL), the ability to write academic text effectively incorporates one of the most significant abilities required. In EFL context, English is taught as a foreign language at schools and universities; therefore, the problem of proficiency in written English becomes even more complicated as a result. Many studies have been conducted in the context of EFL to investigate the different aspects of teaching and learning English as a foreign language, with several these studies reporting that learners face a range of problems in acquiring English language skills (Zughoul \& Taminian, 1984; Abbad 1988; Ahmad, 2003; Rabab'ah, 2005).

Despite the importance of writing in higher educational learning for the purpose of professional communication, academic performance and student achievement and success; previous literature shows that writing in English is one of the biggest challenges faced by students at the university level (Kim, Mendenhall, \& Johnson, 2010). To investigate this problem several studies (Al-Khasawneh \& Maher, 2010; Weshah \& Tomok, 2011), undertaken in an EFL context, have revealed a direct relation between the students' performance at the secondary school level and university level. The findings of these studies suggest that a lack of proficiency in writing skills among university students is negatively influenced by the EFL writing curriculum in secondary schools.

Most writing problems seem to be associated with deficits in teaching and learning at the secondary school level, something which lead to many students having difficulties adapting to the academic writing requirements at a university level (Kruse, Jakobs, \& Ruhmann, 1999). According to Weshah and Tomok (2011) the vast majority of university students have graduated from secondary schools with low levels of communicative English, particularly in the case of written communication skills. Previous studies have revealed that EFL students at university level in many EFL countries appear to face many difficulties despite the lengthy duration of preparation during their secondary school education. For example, in Korea, students receive EFL preparation for 10 years at elementary and secondary school levels (Ahn, 2003)-however, most of them are unable to speak or read English at the university level (Dickey, 2004). In another study focusing on the Middle East, results indicated that many students at university level were poor speakers and writers despite the six years of preparation in primary and secondary schools (Abbad, 1988; Shamsan, 2003).

Consequently, this paper asserts that in improving English academic literacy at the higher education level, an evaluation for the preparation process at the secondary level must come first. To help students get prepared for the required skills at the university level, a systematic investigation into EFL approaches and strategies is required, as are principles of designing the EFL curriculum and the EFL teaching and learning methods as well.

Curriculum is the backbone of any teaching and learning environment. Without a proper curriculum it is difficult to gauge where student are heading (Wallin, 2011). Curriculum evaluation is an essential process in teaching and learning. Through evaluation, the faculty can discovered whether a curriculum is fulfilling its purpose and whether students are actually learning (Di Florio et al., 1989). The discussion of curriculum evaluation in the literature is related to examining the effectiveness of the curriculum in achieving the objectives of the curriculum 
and other evaluation creteria. However, this paper proposes an analytical framework for the evaluation of the secondary curriculum-in particular, the writing curriculum based on the model of Richards and Rodgers (2001). The framework includes six definite steps, namely; investigating the SLA theories and instructional approaches reflected in the secondary EFL writing curriculum; investigating the L2 writing theories and instructional approaches reflected in the secondary EFL writing curriculum; investigating the learner roles reflected in the secondary EFL writing curriculum; investigating the teacher roles reflected in the secondary EFL writing curriculum; investigating the types of writing tasks reflected in the secondary EFL writing curriculum; and, analysing the cognitive demand of the writing tasks within the secondary EFL writing curriculum.

Proposing clearly defined steps for the evaluation process of the curriculum is to be supported with relevant theoretical discussions that will assist educational institutions, curriculum designers and educators in their efforts to develop the EFL writing curriculum for secondary schools, as well as to promote effective teaching and learning strategies that equip students with writing skills needed at the higher education level.

\section{Theoretical Framework}

The purpose of this paper is to propose an analytical framework to guide the preparatory evaluation processes which, in turn, will determine how successful the secondary curriculum is in prepping student for EFL writing skills required at a university level. The analytical framework of analysing the EFL secondary writing curriculum proposed in this research has been influenced by the model of linguistic education devised by Richards and Rogers (2001), as shown in Figure 1. This model suggests language teaching methodological links exist between theory and practice.

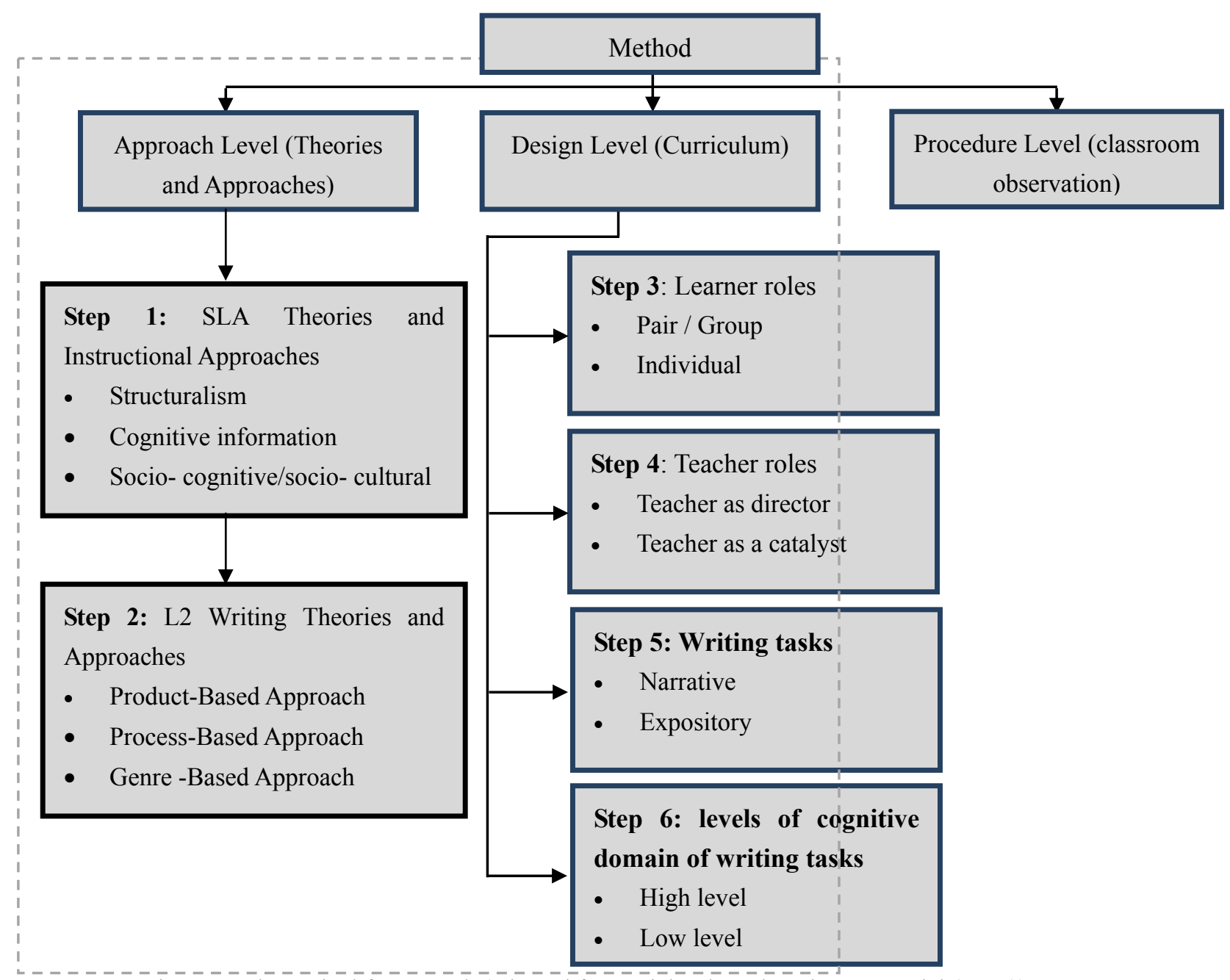

Figure 1. Theoretical framework (adapted from Richards and Rodgers's model (2001)) 
This can be seen through instructional design features in which the analysis of the language instruction can be realized with regards to; the 'Approach Instruction', which subsequently, can be realized with regards to; the 'Approach (hypotheses of linguistic education) Design', for example, particular linguistic demands roles of teachers, roles of learners); as well as the Procedure, such as learning procedure and observations of the teaching process alongside interviews with the educational staff.

As the scope of this paper is limited to the curriculum aspects; which are only found at two levels in Richards and Rodgers (2001), language instruction models are applicable to this study. First, the Approach level provides a principle for the analysis of the secondary EFL writing curriculum in terms of SLA theories as well as L2 writing theories and instructional approaches. Second, in the design level, certain elements can be used to assess the types of writing tasks, the roles of learners and the roles of teachers within the curriculum. However, the procedural level in Richards and Rodgers' (2001) model is related to activities employed by the teacher, which can be gauged through an observation for teachers in the classroom as well as via interviews. Additionally, another evaluation process has been integrated into the model (as devised by Richards and Rogers (2001)) in this paper in order to assess the skill level and cognitive requirements of the writing assignments set as a result of its crucial role as a factor in linguistic proficiency.

\subsection{SLA Theories and Instructional Approaches}

A set of analysis procedures, based on the EFL literature, were developed in order to evaluate the secondary curriculum. The SLA theories and instructional approaches reflected in the EFL secondary writing curriculum can be analysed in relation to three main SLA theories and their related instructional approaches, namely; structural/behaviourism approach, cognitive information processing approach, and the socio-cognitive/ socio-cultural approach.

The structuralism theory approach focuses on language form and structure-for example, within Grammar Translation Method the focus is directed toward certain activities such as translating passages from one language into the other, memorizing grammatical rules and memorizing vocabulary. Additionally, class work activities are highly structured and all activities are typically controlled by the teacher (Larsen-Freeman, 2000). In the case of cognitive information processing the main focus of learning is on linguistic information processing, textual information processing and prior knowledge processing (Koda, 2005). This approach focuses on the process of combining text ideas into coherent sentences in order to assist learners in their analysis the meaning of a section of text beyond the sentence level (Storch, 1998). Direct methods help students to extrapolate deeper meaning directly through the target language, and often visual aids are used to help students understand this meaning. Students speak in the target language and communicate as if in a real life situation. Through such an approach the focus is on writing and reading skills, with the grammar taught deductively. However, Socio-cognitive/socio-cultural theories regarding SLA tend to consider language learning as cognitive and social in nature (Sidek, 2012). According to socio-cognitive theories, learning occurs through the interactive network of cognition, social interaction and the environment (Atkinson, 2002). The communicative approach introduces realistic and normative scenarios into English language education (Xu, 2010), and is similar to the most general learning perspectives, usually referred to as 'learning by doing' or 'the experiential approach' (Richards \& Renandya, 2002).

\subsection{L2 Writing Theories and Approaches}

There are three main approaches regarding writing theories including, product-based approach, process-based approach and genre-based approach. Discussion of each approach is presented in the following sections.

\subsubsection{Product-Based Approach}

The product-based writing approach is a well-established means of education by which the learner is persuaded to mirror a section of example text, often given to them in the nascent stages of learning the language (Gabrielatos, 2002). In an ordinary product approach-cantered class, learners are given an ordinary example of writing, which they are then required to follow and adapt in order to re-create a section of original text.

The product-based approach is the most common and traditional approach used by EFL teachers. Robertson (2008) stated that an over-emphasis on the educator is regularly worsened if educators arrange their curriculum through a product-focused method whereby educators educate from the basis of basic and elementary example texts. Additionally, Brown (2002) proposed that in the case of product-focused methods fruitful learning is determined by the extent to which the text is well-organized, as well as on its grammatical accuracy. It must also be considered that in the product-focus method the learners seldom earn the techniques that are required in the creation and moulding of exercises, something that is due to the over-emphasis on the forms of language as 
stipulated by Robertson (2008). As the use of language involves the manipulation of fixed linguistic patterns, a student is thus not permitted to devise within the language that is being learned itself. Such trends are acquired through repetition and recreation. Pincas (1982) provides explicit descriptions of product approaches; stating that writing is primarily about accruing linguistic knowledge and using vocabulary and syntax appropriately. Furthermore the method, as stated by Nunan (1999), agrees with the sentence strata structuralizing of language and bottom-to-top cognition.

There are several procedures of learning in product-oriented writing that may serve to improve learner competency, as well as their understanding of a second language and writing system from the basic level. Regardless, the trend-product writing method is generally adopted by educators as due to the fact that there are several benefits to its use while learners practice in class. Firstly, learners understand how to practice the components of the English language through a writing system and the use of the trend-product means-that is; the trends within certain aspects of written English such as descriptive technique, narrative and suggestive or rhetorical writing. Additionally, learners learn how to employ a range of words and structure their sentences depending on each trend in their writing. Finally, we consider the product-based approach-writing with the product-based approach affords little attention to the perspective as learners and instructors tend to focus on grammar and syntax. In this case, students will lack motivation in performing writing tasks perfectly as instructors mainly focus on the structure and the accuracy of the language used.

\subsubsection{Process-Based Approach}

Currently, a process-approach is being adopted in English language writing education, which is converse to the more traditional product-focused approach in educating learners. It has been adopted and used by teachers for the benefit of their classes in the subject of English writing (Sun \& Fang, 2009). Process-focussed writing is seen as the means by which writers can improve their writing tasks from an immediate stage to the stage which sees their pre-cuts completed.

The concept of the process-based approach has been defined by O'Brien (2004) as; an activity by which teachers encourage students to see writing, not in terms of grammatical exercises, but in terms of meaning and discovery of ideas. According to Tribble (1990), process writing can be considered as a means of teaching English in written form, impressing the importance of creativity upon the writer and focusing on the creation of positive writing for positive writing methods, as opposed to merely imitating a model by rote. Additionally, Silva and Matsuda (2001) argue that a process-based approach is an approach that emphasizes the teaching of writing as a process; helping students to discover their own voice. Throughout the writing process it is difficult to follow the static sequence of writing stages, thus, in order to invent better concepts of writing, writers need to alternate between different techniques of writing. Therefore in the process approach, writing could be perceived as a pragmatic and varying practice (Tribble, 1990).

When comparing the process-based approach to the product-based approach, it can be determined that the advantages of the process approach lie in the fact that it has been acknowledged and assigned to the EFL, and ESL educational meetings due its many successes. In one example, that of the product method, focus is placed upon the end-product of the educational process and the individual undergoing education is assumed to be able to seek and write as a fluent and proficient user of the English language. The process approach, however, puts particular importance on the process that the writer undergoes when devising and creating a piece of text. In accordance with Nunan (1991) and Brown (2002), the product-focused method sees a considerable amount of stress placed on example creations of writing that the learner could replicate. It also focused on the extent to which the student successfully managed to create a product that matched the series of requirements demanded, including; organization, use of vocal, accurate use of grammar and exemplified example of linguistic mechanism such as spelling and punctuation. Conversely, within the process approach learners control their own creations of writing by being able to consider as they write (Brown, 20020)-this is to say, learners are able to impart and convey their own particular opinion to the reader through a multifaceted process of writing, specifically; pre-writing, creating draft pieces, revisions and emended texts. The next argument is that process method is useful to those learning languages as the they, as the creator of the language, re thus required to investigate both content, as well as the argument or opinion of the piece respectively. Moreover, Tribble (1996) states the process method came from an alternative aim of the product method as the process method is; "a method that teaches writing that places great importance on the ability and individuality of the particular writer, and which also focuses on the creation of solid wiring processes rather than the rote recreation of model text". Rimes (1983) showed that in the process method, learners do not write on a particular topic in a particular timeframe before returning their work to the educator. Instead, learners look into the subject through their writing-a method that proves to be hugely useful to the learner as it puts greater emphasis on varied class exercises. 
When a variety of community practices are used in writing educational classes, learners give feedback or suggestions on the process and write together as a joint effort on an assignment. Nunam (1991) suggested that the group method encourages the practice of sharing of knowledge between individual learners, and therefore seems to motivate and create a positive outlook on the learning process as a whole. Within the process approach, learners become motivated to use their resources and focus with greater emphasis on fluency rather than accuracy. Conversely, as has been previously discussed, teachers adopting the product-approach focus on accuracy and linguistics patterns, however, it is fair to conclude that both accuracy and fluency are required if students are to better their abilities in language and develop solid communication method in English.

\subsubsection{Genre-Based Approach}

Recently, genre-based approaches regarding the English writing teaching practices have started to appear. The concept originated in Australia, though is now evident in English classes across New Zealand and Australia, as well as some other countries (Ahlsén \& Lundh, 2008). Byram (2004) defined the genre approach as; "a framework for language instruction"; while Swales (1990) identified a genre as "a class of communicative events, the members of which share some set of communicative purposes". This approach-model is more of a functionalistic in its method, and emphasizes the social constructiveness of language (Knapp \& Watkins, 2005). Within the genre approach, text is seen as a social process and writing as a collaborative act that is affected by a multifaceted by interconnected social phenomena (Knapp \& Watkins, 2005). As reported by Hyland (2004), genre approach adherents argue that people write to fulfil a particular goal or to achieve a certain purpose; that people do not only write to practice grammar or learning structures, but also to focus on context and readership. Furthermore, Hyland (2004) asserts that the idea of 'genre' supports allows educators to perceive beyond the content of the writing itself to perceive the process behind it, as well as see forms of text that determine how writing becomes a means of interact with the reader. Additionally, Knapp and Watkins (2005) state that the aim of the genre approach is to support learners in their utilization of codes for the purpose of useful and proficient writing, and these codes stem from separate genres; such as of a descriptive or argumentative focus. Those who favour the technique suggest that genre approach is the most modern and proficient means of education with regards to writing skills, since it focuses on both culture and ways of writing-and the layout of the writing is connected to the respective culture (Hyland, 2004).

The genre approach systematically incorporates discourse and contextual aspects of the language, creating the awareness of readership, variation in the text and structure of the writing itself, and is not merely matter of training students to reproduce a certain form. The approach also helps students in recognizing how texts can be created to relate to a specific purpose, readership or message (Derewianka, 2003; Hyland, 2004). This approach is empowering since it provides EFL learners with knowledge and understanding of the typical patterns and the powerful genres of culture Consciousness-raising is described as; an approach that supports learners in their analysis of the means by which information and knowledge are laid out in formal English textual examples. Kay and Dudley (1998) argue that the genre method is better for those learners who hope to increase their witting skills as a second language over that of the process method, as the genre method assists in freeing learners from previously held hesitations concerning their accuracy of writing.

To elaborate, the aim of writing with regards to this perspective is to inculcate the knowledge of an exact genre and its communicative aim - something that could help students to produce a writing work that conveys certain information to other individuals in the same interactive group of demographics successfully. In order to successfully implement the genre-based approach, English teachers (Ahlsén \& Lundh, 2008) must suggest several exemplary example texts that show particular examples of the particular text-type to learners in the class (Ahlsén \& Lundh, 2008). In accordance with Badger and White (2000), writing through or within the genre method can be seen as an elongation of the product method mentioned above; it gives learners the means by which to study several writing techniques including formal letters, academic reports and research assignments. Consequently, this approach could help students realize the purpose, language features and structure of a given text. Learners could then use this knowledge to write effectively (Luu \& Tuan, 2011). As a result, the learning of particular genre constructions may be seen as a means to assist students in devising a more accurate way of writing in their normative lives outside of the class environment. By the compositional process (Miller, 1997; Candlin, 1999), genre-based writing shows the assessment of each genre of writing (Badger \& While, 2000).

\subsection{Learner Roles}

Based on Richards and Rodger's (2001) perspective, learner's role patterns are banded into 'individual', 'pair' or 'group'. According to Vygotsky (2000) in the case of learners integrating with one another, learners can create an understanding on the basis of another's understanding, thereby increase their competency overall. As a result, 
pairing and grouping activities prove indispensable in the class environment, allowing learners to work with each other and, when they are working in collaboration, more competent learners can work with less-competent learners to assist them. Grouping activities affect the education of a language as it gives learners an opportunity to interact with a readership. Pair and group activities are supported implicitly in the communicative approach as the focus of the communicative approach with regard to social interaction, and the use of language rather than on language structure (Lightbow \& Spada, 1999). Many researchers emphasise the importance of peer involvement and pair work in enhancing students' confidence, stressing the significance of the involvement of peers in collaborative work and supporting learner confidence. To summarise, within this paper it has been suggested that learner roles can be coded based on the description of Richards and Rodger (2001) and Johnson and Paulston (1976). The learner roles contain the types of learning tasks set for learners in the form of learning assignments, given to students in terms of learner groupings, whether they are individual or pair/group.

\subsection{Teacher Roles}

Richards and Rodgers (1986) assert that teacher roles are related to a set of issues including: (a) the kind of job teachers are required to fulfil; (b) the extent of control an educator has over the learning practices adopted; (c) the extent to which the teacher can decide what is to be used as part of the educational process and; (d) the trends of interaction that come about between learners and educators. Larsen-freeman (2000) and Littlewood (1981) inculcate the role of the language toward the educator as the enabler of learning' in lieu of Communicative Language Teaching (CLT). Harmer (2001) points out that the teachers' role can be described as a controller, organizer, assessor, prompter, tutor, and observer. According to Tudor (1993), within the context of a learner-cantered classroom the learning process should stress the importance of the active participation of the students. The role of the teacher in the learner-cantered approach is to provide activities that stimulate the acquisition of skills and knowledge through communication (Klapper, 2003), facilitate communicative process between participants in the classroom; and encourage activities among participants (Breen \& Candlin, 1987). In this paper, it has been suggested that for evaluation the teacher roles in the secondary writing curriculum, the roles can be classified and coded under two categories teacher as a director and teacher a catalyst. In order to help students to be equipped with the academic writing skills required at a university level, the secondary curriculum should impart more emphasis on the role of the teacher as a facilitator rather than as director. Promoting a learner-cantered environment will create an opportunity for students to improve their language skills through self-reflection and peer-reflection, and this will result in students being more capable when working indecently on variety of writing tasks, as well as being better equipped to meet the challenges they may face at a university level.

\subsection{Types of Writing Tasks}

In preparing student for university courses, it is essential to possess information about the different forms of writing assignments (Shih, 1986). A study conducted by Rose (1983) attempted to determine writing tasks in classes at the University of California. In the study, 445 assignment and home exam and subject matters from 17 departments of the University were collected and analysed. The study results revealed that the most questions and topics at university specifically required;

“...(a) exposition and academic argument, (b) synthesis of information from lectures and readings (rather than ideas from personal experiences or observations of immediate objects or events) and thoughtful reflection on material, and (c) writing which fits the philosophical and methodological assumptions of specific academic disciplines" (Rose, 1983).

The type of writing tasks assigned in university courses may vary from one academic level to another. Generally speaking, students use writing within different fields of academia, with graduate compared to undergraduate. Students utilise writing as a means to demonstrate their knowledge (in exams, assignments etcetera and so on), just as educators utilise it as a means of starting individualistic thinking; for research or study papers and literature reviews and critiques etcetera (Shih, 1986). In this paper, it is suggested that writing tasks can be classified into narrative and expository (Derewianka, 1990; Avalos et al., 2007). Within this research it is proposed that a writing task in the curriculum that focuses on exposition and academic argument (Rose, 1983), critical analysing, or the synthesis of information from several sources (Pugh et al., 2000) to be labelled as an expository writing task. In contrast to the expository, narrative tasks can be labelled as writing tasks that are assigned for the purpose of describing personalized experiences or perceptions of instant objects or occurrences, and that providing factual descriptions through the summarizing of ideas and/or information contained within a text-narrating events or report facts will be labelled as narrative tasks.

In the university level, students need to be prepared to read and write texts that are primarily expository (Pugh et 
al., 2000). Consequently, if EFL instruction at the secondary level focuses on training students more so toward on narrative writing, than with regards to expository writing students might face difficulties in writing academically at the university level; which is mostly expository in nature. Therefore, to prepare students for EFL writing at a university level, writing instructions that expose students to expository writing tasks may assist in equipping them with the required writing skill at the university level.

\subsection{Cognitive Demand Levels of Writing Tasks}

The current research also focuses on analysing the levels of cognitive demand of the writing skills in the secondary EFL writing curriculum. This is required in order to acquire data on the types of writing tasks for which secondary school students are prepared. To determine the cognitive levels of the writing tasks, a coding scheme was developed based on the revised version of Bloom's taxonomy of cognitive domain level (Anderson, Krathwohl, \& Bloom, 2001).

Table 1. Bloom's Taxonomy cognitive levels and key words (Bloom, 2013)

\begin{tabular}{|c|c|c|c|}
\hline Levels & Skill & Definition & Keywords \\
\hline Level 1 & Knowledge & Recall information & $\begin{array}{l}\text { Identify, describe, name, label, } \\
\text { recognize, reproduce, follow }\end{array}$ \\
\hline Level 2 & Comprehension & $\begin{array}{l}\text { Understand the meaning, paraphrase } \\
\text { a concept }\end{array}$ & $\begin{array}{l}\text { Summarize, convert, defend, } \\
\text { paraphrase, interpret, give examples }\end{array}$ \\
\hline Level 3 & Application & $\begin{array}{l}\text { Use the information or concept in a } \\
\text { new situation }\end{array}$ & $\begin{array}{l}\text { Build, make, construct, model, } \\
\text { predict, prepare }\end{array}$ \\
\hline Level 4 & Analysis & $\begin{array}{l}\text { Break information or concepts into } \\
\text { parts to understand it more fully }\end{array}$ & $\begin{array}{l}\text { Compare/contrast, break down, } \\
\text { distinguish, select, separate }\end{array}$ \\
\hline Level 5 & Synthesis & $\begin{array}{l}\text { Put ideas together to form something } \\
\text { new }\end{array}$ & Categorize, generalize, reconstruct \\
\hline Level 6 & Evaluation & Make judgments about value & $\begin{array}{l}\text { Appraise, critique, judge, justify, } \\
\text { argue, support }\end{array}$ \\
\hline
\end{tabular}

Blooms' taxonomy of cognitive domain (Krathwohl, 2002) is a scaffold for determining the class of statements of what it would predict the particular learner to be able to learn under instruction (Krathworhl, 2002). The cognitive domain includes knowledge and the improvement of intellect (Bloom, 1956). There are six main categories of Blooms' taxonomy of cognitive thinking, starting from the lower level of thinking up to the most complex. There are six categories in the original taxonomy, namely; 'Knowledge', 'Comprehension', 'Application', Analysis', 'Synthesis', and 'Evaluation'. The cognitive levels and key words of Bloom's Taxonomy are shown in Table 1. The revised Taxonomy (Krathwohl, 2002), published by Lorin Anderson and his collaborators has had the widest acceptance. The authors describe their work as an elongation of the original blueprint, rather than an alternative. The new taxononomy was revised and founded on the preconcert of new learning and as an innovative means of implementing instructive education (Bloom, 2013).

The revised Taxonomy cognitive levels and keywords is shown in Table 2. The writing exercises and tasks of the curriculum have to be aligned and codified based on Bloom's definitions at different levels of the cognitive domain. The frequency of occurrence of the writing skills to use in order to achieve learning outcomes can also be calculated. An example of the coding scheme is as shown in Table 2. These taxonomies describe the cognitive skills that students are required to possess at various levels of cognitive demand. One of the foremost aims of the EFL secondary curriculum is to prepare students for higher education. Therefore, learners are required to be aware of lower cognitive requirements such as remembering facts and arguments, but also higher-level skills such as the means to assess and employ new information learned. 
Table 2. Revised Taxonomy cognitive levels and key words adapted from (Krathwohl, 2002)

\begin{tabular}{|c|c|c|c|}
\hline Levels & Skill & Definition & Keywords \\
\hline Level 1 & Remembering & $\begin{array}{l}\text { Retrieving relevant knowledge from } \\
\text { memory }\end{array}$ & $\begin{array}{l}\text { Define, describe, find, identify, label, } \\
\text { list, match, name, outline, recall, } \\
\text { recognise }\end{array}$ \\
\hline Level 2 & Understanding & $\begin{array}{l}\text { Determining the meaning of } \\
\text { instructional messages, including } \\
\text { oral, written, and graphic } \\
\text { communication }\end{array}$ & $\begin{array}{l}\text { Summarize, translates interpret, } \\
\text { paraphrase, rewrite, explain, classify, } \\
\text { infer, compare, explain, give } \\
\text { examples }\end{array}$ \\
\hline Level 3 & Applying & $\begin{array}{l}\text { Carrying out or using a procedure in } \\
\text { a given situation. }\end{array}$ & $\begin{array}{l}\text { Execute, use, apply, implement, } \\
\text { illustrate, prepare, demonstrate }\end{array}$ \\
\hline Level 4 & Analysing & $\begin{array}{l}\text { Breaking material into its } \\
\text { constituent parts and detecting how } \\
\text { the parts relate to one another and to } \\
\text { an overall structure or purpose }\end{array}$ & $\begin{array}{l}\text { Analyse, breaks down differentiate, } \\
\text { contrast, organize, deconstruct, edit, } \\
\text { distinguish, review }\end{array}$ \\
\hline Level 5 & Evaluating & $\begin{array}{l}\text { Making judgments based on criteria } \\
\text { and standards. }\end{array}$ & $\begin{array}{l}\text { Assess, check, criticize, evaluate, } \\
\text { justify, prioritize, interpret }\end{array}$ \\
\hline Level 6 & Creating & $\begin{array}{l}\text { Putting elements together to form a } \\
\text { novel, coherent whole or make an } \\
\text { original product }\end{array}$ & $\begin{array}{l}\text { Generate, create, plan, produce, } \\
\text { compose, refine, revise, synthesize, } \\
\text { develop, reconstructs }\end{array}$ \\
\hline
\end{tabular}

The analysis of the cognitive demands of the writing tasks at the secondary school level may provide insights into the level of EFL writing mastery. If the cognitive demands of the writing tasks in the EFL secondary writing curriculum are primarily at knowledge retrieval and comprehension levels of taxonomy, secondary students are thus perhaps ill prepared for the necessitates regarding cognitive ability of writing assonants in EFL that the University level demands.

\section{Conclusion}

The application of effective academic writing is one of the most important skills students are required to possess for higher education learning and overall academic achievement and success therein. However, it remains a major challenge for students in an EFL learning context. Revisiting the process of preparation at a secondary level is a recommended approach for improving the language and academic literacy at a university level. To guide the evaluation processes of curriculum, an analytical framework has been proposed in this paper that includes five steps regarding the investigation of how well the EFL writing curriculum prepares students with required academic writing skills for university. This framework seeks to be a helpful tool, and provide guidelines for English Curriculum evaluation and development studies in the educational field. Moreover, this study will provide a clear idea on how well the EFL secondary writing curriculum is to prepare students for subsequent levels of higher educational studies. Knowing this, the higher education institutions, curriculum designers, and teachers can actually plan for improvement of English language acquisitioned skills. Using the proposed framework and utilising the proposed evaluational steps in demonstrating a practical evaluation study in order to analyse the EFL curriculum in a particular writing curriculum is recommended for future studies.

\section{References}

Abbad, A. T. (1988). An analysis of communicative competence features in English language texts in Yemen Arab republic (Doctoral dissertation, University of Illinois at Urbana-Champaign).

Ahlsén, E., \& Lundh, N. (2008). Teaching Writing in Theory and Practice: A Study of Ways of Working with Writing in the 9th Grade. Retrived from http://www.diva-portal.org/smash/get/diva2:199311/FULLTEXT01. pdf

Ahmed, A. H. (2010). Students' Problems with Cohesion and Coherence in EFL Essay Writing in Egypt: Different Perspectives. Literacy Information and Computer Education Journal (LICEJ), 1, 211-221.

Ahn, S.-H. (2003). A case study of a Korean learner. Asian EFL journal, 5, 1-27. 
Al-Khasawneh, F. M. S., \& Maher, S. (2010). Writing for academic purposes: Problems faced by Arab Postgraduate students of the College of Business, UUM. ESP World, 9, 1-23.

Anderson, L. W., Krathwohl, D. R., \& Bloom, B. S. (2001). A taxonomy for learning, teaching, and assessing: A revision of Bloom's taxonomy of educational objectives. Longman.

Atkinson, D. (2002). Toward a sociocognitive approach to second language acquisition. The Modern Language Journal, 86, 525-545. http://dx.doi.org/10.1111/1540-4781.00159

Avalos, M. A., Plasencia, A., Chavez, C., \& Rascón, J. (2007). Modified guided reading: Gateway to English as a second language and literacy learning. The Reading Teacher, 61, 318-329. http://dx.doi.org/10.1598/RT.61.4.4

Badger, R., \& White, G. (2000). A process genre approach to teaching writing. ELT journal, 54, 153-160. http://dx.doi.org/10.1093/elt/54.2.153

Bloom, B. S. (2013). Taxonomy of Educational Objectives. Retrieved from http://educationalelearningresources. yolasite.com/resources/guildresearch_blooms2013.pdf

Bloom, B. S., Engelhart, M., Furst, E. J., Hill, W. H., \& Krathwohl, D. R. (1956). Taxonomy of educational objectives. New York: David McKay.

Breen, M. P. (1987). Learner contributions to task design. In C. N. Candlin, \& D. F. Murphy (Eds.), Language learning tasks (pp. 23-46). Prentice Hall.

Brown, H. D. (2002). English language teaching in the "post-method" era: Toward better diagnosis, treatment, and assessment. Methodology in language teaching: An anthology of current practice, 9-18. http://dx.doi.org/10.1017/CBO9780511667190.003

Byram, M. (2004). Genre and genre-based teaching. The Routledge Encyclopedia of Language Teaching and Learning. London: Routledge.

Candlin, C. N. (1987). Towards task-based language learning. In C. N. Candlin, \& D. Murphy (Eds.), Language learning tasks (pp. 5-22). Prentice-Hall.

Candlin, N. C. et al. (1999). Writing: Texts, Processes and Practices. New York: Longman.

Collins, L., Halter, R., Lightbown, P., \& Spada, N. (1999). Time and the distribution of time in second language instruction. TESOL Quarterly, 33, 655-680. http://dx.doi.org/10.2307/3587881

Crystal, D. (2003). English as a Global Language. Cambridge University Press. http://dx.doi.org/10.1017/CBO9780511486999

Derewianka, B. (2003). Trends and issues in genre-based approaches. RELC Journal, 34, 133-154. http://dx.doi.org/10.1177/003368820303400202

Dickey, R. (2004). Public finance: Mountain Valley (Korean) National Polytechnic University. Retrieved from http://www.content-english.org/data/reports/pf-mvu.rtf

Diflorio, I., Martin, B., Middlemiss, M. A., \& Duncan, P. A. (1989). Curriculum evaluation. Nurse Education Today, 9, 402-407. http://dx.doi.org/10.1016/0260-6917(89)90095-6

Emig, J. (1978). Hand, eye, brain: Some "basics" in the writing process. Research on Composing Points of Departure. In C. Charles, L. Odell, \& U. Ill (Eds.), National Council of Teachers of English (pp. 59-72).

Gabrielatos, C. (2002). EFL Writing: Product and Process. Karen's Linguistic Issues.

Harmer, J. (2001). The practice of English language teaching. London: Longman.

Hasbollah, H. R. B. (2010). The writing performance of undergraduates in the University of Technology Mara, Terengganu, Malaysia. Journal of Languages and Culture, 1, 8-14.

Hyland, K. (2004). Genre and Second Language Writing. University of Michigan Press.

Jakobs, E.-M., Ruhmann, G., \& Kruse, O. (1999). Schlüsselkompetenz schreiben: Konzepte, Methoden, Projekte für Schreibberatung und Schreibdidaktik and der Hochschule: Luchterhand.

Jones, E. A. (1995). National Assessment of College Student Learning: Identifying College Graduates' Essential Skills in Writing, Speech and Listening, and Critical Thinking. Final Project Report.

Jung, S., \& Norton, B. (2002). Language Policies in Education: Critical Issues. In J. Tollefson (Ed.), Language Planning in Korea: The New Elementary English Program. Lawrence Erlbaum Associates, Inc. Publishers. 
Kay, H., \& Dudley-Evans, T. (1998). Genre: What teachers think. ELT Journal, 52, 308-314. http://dx.doi.org/10.1093/elt/52.4.308

Kellogg, R. T., \& Raulerson, B. A. (2007). Improving the writing skills of college students. Psychonomic bulletin \& review, 14, 237-242. http://dx.doi.org/10.3758/BF03194058

Kim, C., Mendenhall, A., \& Johnson, T. (2010). A Design Framework for an Online English Writing Course. In J. M. Spector, D. Ifenthaler, P. Isaias, Kinshuk, \& D. Sampson (Eds.), Learning and Instruction in the Digital Age. Springer US.

Klapper, J. (2003). Taking Communication to task? A critical review of recent trends in language teaching. Language Learning Journal, 27, 33-42. http://dx.doi.org/10.1080/09571730385200061

Knapp, P., \& Watkins, M. (2005). Genre, text, grammar: Technologies for teaching and assessing writing. UNSW Press.

Koda, K. (2005). Insights into second language reading: Across-linguistic approach. Cambridge Press: New York. http://dx.doi.org/10.1017/CBO9781139524841

Krathwohl, D. R. (2002). A Revision of Bloom's Taxonomy: An Overview. Theory into Practice, 41, 212-218. http://dx.doi.org/10.1207/s15430421tip4104_2

Larsen-Freeman, D. (2001). Techniques and Principles in Language Teaching. Oxford: Oxford University Press.

Littlewood, W. (1981). Communicative language teaching: An introduction. Cambridge University Press.

Luu, T. T. (2011). Teaching writing through genre-based approach. BELT-Brazilian English Language Teaching Journal, 1, 1471-1478.

Mckay, S. L. (2002). Teaching English as an International Language: An introduction to the role of English as an international language and its implications for language teaching. OUP Oxford.

Miller, T. (1997). Functional Approaches to Written Text: Classroom Applications. Washington, DC: USIA.

Myles, J. (2002). Second language writing and research: The writing process and error analysis in student texts. TESL-EJ, 6, 1-20.

Nunan, D. (1991). Language teaching methodology: A textbook for teachers. Prentice hall United Kingdom.

Nunan, D. (1999). Second Language Teaching \& Learning. ERIC.

Nunan, D. (2003). The Impact of English as a Global Language on Educational Policies and Practices in the Asia-Pacific Region. TESOL Quarterly, 37, 589-613. http://dx.doi.org/10.2307/3588214

Pincas, A. (1982). Teaching English Writing. Macmillan Press.

Prior, S. V. (2012). An Exploration of Changes in First-Year College Students' Writing Skills Between High School and the Conclusion of the Composition Course (Doctoral dissertation). Retrieved from http://scholarcommons.sc.edu/etd/1033

Pugh, S. L., Pawan, F., \& Antommarchi, C. (2000). Academic literacy and the new college learner. Lawrence Erlbaum Associates Publishers

Rabab'ah, G. (2005). Communication problems facing Arab learners of English. Journal of Language and Learning, 3, 180-197.

Raimes, A. (1983). Techniques in Teaching Writing. ERIC.

Reigstad, G. R. (2008). Best Practice in Writing Instruction K-8. Retrieved from http://differentiatedinstruction.efoliomn.com/Uploads/Written Language Research.doc

Richards, J. C., \& Nunan, D. (1990). Second language teacher education. Cambridge University Press.

Richards, J. C., \& Renandya, W. A. (2002). Methodology in language teaching: An anthology of current practice. Cambridge University Press. http://dx.doi.org/10.1017/CBO9780511667190

Richards, J. C., \& Rodgers, T. S. (2001). Approaches and methods in language teaching. New York: Cambridge University Press. http://dx.doi.org/10.1017/CBO9780511667305

Robertson, C. (2008). Integration of Moodle Course Management System (CMS) into an EFL Writing Class. The JALT CALL Journal, 4, 53-59.

Rose, M. (1983). Remedial writing courses: A critique and a proposal. College English, 45, 109-128. http://dx.doi.org/10.2307/377219 
Shih, M. (1986). Content-Based Approaches to Teaching Academic Writing. Tesol Quarterly, 20, 617-648. http://dx.doi.org/10.2307/3586515

Sidek, H. M. (2010). An Analysis of the EFL Secondary Reading Curriculum in Malaysia: Approaches to Reading and Preparation for Higher Education (Doctoral dissertation, University of Pittsburgh).

Silva, T., \& Matsuda, P. (2001). On second language writing. Mahwah, NJ: Lawrence Erlbaum.

Songy, D. G. (2007). Predicting success in academic achievement of major seminarians in Papua New Guinea: A comparison of cognitive test results and grade point averages, 7, 59-71.

Storch, N. (1998). A classroom-based study: Insights from a collaborative text reconstruction task. ELT Journal, 52, 291-300. http://dx.doi.org/10.1093/elt/52.4.291

Stoynoff, S. (1997). Factors associated with international students' academic achievement. Journal of Instructional Psychology, 24, 56-68.

Sun, C., \& Feng, G. (2009). Process approach to teaching writing applied in different teaching models. English Language Teaching, 2, 150. http://dx.doi.org/10.5539/elt.v2n1p150

Swales, J. M. (1990). Genre analysis: English in academic and research settings. Cambridge: Cambridge University Press.

Tangpermpoon, T. (2008). Integrated approaches to improve students writing skills for English major students. ABAC Journal, 20, 1-9.

Tribble, C. (1990). Concordancing and an EAP writing programme. CAELL Journal, 1, 10-15.

Tudor, I. (1993). Teacher roles in the learner-centred classroom. ELT Journal, 47, 22-31. http://dx.doi.org/10.1093/elt/47.1.22

Vygotsky, L. S. (1978). Mind in society: The development of higher psychological processes. Cambridge, MA: Harvard University Press.

Weshah, H. A., \& Tomok, T. N. (2011). Patents/Apps Non-Patent Literature.

White, R., \& Arndt, V. (1991). Process Writing. Harlow: Longman

Widdowson, H. (1978). Teaching Language as Communication. Oxford. Oxford University press.

Williams, D. (1983). Developing criteria for textbook evaluation. ELT journal, 37, 251-255. http://dx.doi.org/10.1093/elt/37.3.251

$\mathrm{Xu}, \mathrm{Y}$. (2010). Theories Analyzing Communicative Approach in China's EFL Classes. English Language Teaching, 3, 159. http://dx.doi.org/10.5539/elt.v3n1p159

Zughoul, M. R., \& Taminian, L. (1984). The linguistic attitudes of Arab university students: Factorial structure and intervening variables. International Journal of the Sociology of Language, 50, 155-179.

\section{Copyrights}

Copyright for this article is retained by the author(s), with first publication rights granted to the journal.

This is an open-access article distributed under the terms and conditions of the Creative Commons Attribution license (http://creativecommons.org/licenses/by/3.0/). 